\title{
Sint Maarten (Dutch Part)
}

National Cancer Institute

\section{Source}

National Cancer Institute. Sint Maarten (Dutch Part). NCI Thesaurus. Code C101226.

A country comprising the southern portion of an island in the Caribbean sea, between

Anguilla and Saint Barthelemy, a constituent country of the King dom of the Netherlands. 